\title{
Organizational Conflict Management Styles And Industrial Harmony In Nigerian Manufacturing Firms
}

\author{
${ }^{1}$ christine .A. Nwuche (Ph.D); ${ }^{2}$ edwinah Amah (Ph.D) \\ Department Of Management University Of Port Harcourt
}

\begin{abstract}
The inevitability of conflict in the workplace in an undisputed reality and so also is the need for its effective handling in order to mitigate unwanted outcomes. Using 3 conflict management styles from the Thomas-Kilman model (1974) namely, collaborating, compromising and accommodating styles, the study investigated (a) the use of these styles by management of some manufacturing firms in Port Harcourt, Nigeria to handle conflict and $(b)$ the relationship between the styles and industrial harmony measured by low strike incidence and mutuality. We hypothesized that no significant relationship exists between the styles and industrial harmony. A cross-sectional survey design was adopted. Questionnaire was administered to a sample of 240-respondents drawn, using Krejcie and Morgan (1972) table, from a population of 642 employees. 219 copies of returned questionnaire were usable. Data generated were analysed using both descriptive and inferential statistics. Results revealed just about average use of the styles in the management of conflict and that all the styles highly correlated industrial harmony but comparatively more so with the collaborating style. The study concludes that there is need to look beyond conflict management styles in explaining the control of conflict and the achievement of relative harmony in the workplace. We recommend a greater involvement of employees in decisions when conflictual situations are confronted as well as an extension of the tenets of the collaborating styles to include a more integrative problem-solving.
\end{abstract}

Keywords: Conflict management styles, industrial harmony, manufacturing firms.

\section{Introduction}

Industrial harmony may be described as a state of relative peace and cordiality, characterized by trust, unity of purpose and an absence of discontent in organizational relationships (Bassey, Ojua, Archibong and Bassey, 2012; Akume and Abdullahi, 2013; Okpu and Kpakol, 2015). In this scenario, organizational members understand the expectations, are committed and work towards achieving them. This "ideal form" industrial harmony wears a unitarist toga presenting a picture that appears to exclude conflict. However, the existence of conflict in organizational life, which would potentially brew disharmony, is an unquestionable reality. In this respect, Weihrich, Cannice \& Koontz (2011:299) opine that "conflict is a part of organizational life" and Mullins and Christy (2013:99) are certain that "conflict will continue to emerge despite management attempt to suppress it". Thus, on one hand is the desirability of workplace harmony but on the other is the inevitability of organizational conflict.

The workplace is comprised of people from different backgrounds. These individuals have different personalities, perceptions, values, behaviours, needs, interests and goals but are all brought together to contribute in the pursuance of certain goals. Achievement of organizational goals requires cooperation among members but the inherent differences, the incompatibility of goals and the competition for limited resources coupled with "... complex relationships and a high degree of task interdependence" (Weihrich et al; 2011) mean that conflict would be inevitable. At issue, therefore, is what organizations do in their management of conflict so as to achieve reasonable levels of harmony and maintain the "applecart" of organizational activities.

Further complication derives from the point that there are different sources and types of conflict (Weihrich et al, 2011; Mullins \& Christy, 2013; Singh, 2013). Conflict may occur within the individual who is incapable or uncertain about the job expectations and demands, perhaps on account of one's physiological, psychological or personality make up. It may occur between individuals possibly for reason of differences in personality, needs values, beliefs, goals or violation of territory. It may also occur between the individual and the group which often is not unrelated to inability to conform to group rules, norms and values; and/or between groups such as conflict between line and staff positions, between work groups or indeed collective conflict between labour and management (Weihrich et al. 2011; Singh 2013; Mullins and Christy, 2013; Kassim and Ibrahim, 2014; Aylott, 2014).

Several studies have been carried out in the area of conflict, its management and its effects in organizational settings. Thomas and Kilman's (1974; in Singh, 2013) analysis identified 5 conflict management styles comprising the competing, collaborating, compromising, avoiding and accommodating styles. Similarly, Rahim and Magner (1995) identified 5 styles namely integrating, obliging, compromising dominating and avoiding styles. Using the Rahim-Magner model in their study of conflict management styles and organizational 
commitment of bank employees, Kassim and Ibrahim (2014) found that only 3 of these namely, integrating, obliging and compromising significantly correlated and predicted the variations in employees' commitment to the organization. Green and Mark (2001) had found that integrating style promote better understanding among team members. Chan, Huang and Peng (2007) studies concluded that effective conflict management results in positive outcomes such as job satisfaction, good supervisor-subordinate relationship, and cooperation, all of which may be assumed to be indices of harmony.

Generally, many of these studies tend to look at conflict management styles in relation to interpersonal conflicts; specifically, how individuals and team members attempt to handle conflict situations they face at work, not necessarily managers' management to conflict with employees. It is this gap that the current study seeks to fill. Drawing from the Thomas-Kilman (1974) model, the study investigates whether managers adopt these styles in the management of conflict that arise between management and the managed. It situates the investigation in manufacturing firms in Rivers State, Nigeria, the main concerns being to ascertain whether managers use the conflict styles; if they do, what style predominate, and whether these styles are associated with the achievement of relative harmony in the organizations studied.

\subsection{The Nature of Conflict}

\section{Literature Review}

Conflict is inherent in human relations and varied definitions and interpretations of conflict are proffered in the literature. While some definitions draw on behavioural elements, others hinge on outcomes. For instance, Mullins and Christy (2013:98) recognize conflict as "behaviour intended to obstruct the achievement of some other person's goals" and Singh (2013:26) defines conflict as "a disagreement through which the parties involved perceive a threat to their needs, interests or concerns". Aylott (2014:35) sees conflict as "the struggle to ensure ... needs or interests are met" and Appelbaum, Abdallah and Shapiro (1999:62) would similarly opine that conflict is "a process of social interaction that involves a struggle over claims to resources, power and status, beliefs...." Coser (2004) profers that conflict is triggered by differences in values and the struggle for status and control of scarce resources, and it aims to neutralize, injure or eliminate the opponent. Hence conflict could be seen as resulting from incompatibility of goals, differences in attitudes and behaviours (Deutsch, 1973; Mullins and Christy, 2013; Kassim \& Abrahim, 2014) and the struggle for power and influence.

There are varied perspectives concerning the role of conflict in organizations. Many see conflict as a negative phenomenon and as such should be avoided while others recognize that conflict in organizations do have a positive side. In the traditional perspective, organizational conflict is dysfunctional resulting from miscommunication, “... a lack of openness and trust between people, and the failure of managers to be responsive to the needs and aspirations of their employees" (Singh, 2013:28). Managers are expected to identify and remedy this unacceptable malfunctioning in the work group and/or organization which is likely to "harm employee's commitment towards the organization" (Kassim \& Ibrahim, 2014:45).

On the other hand, labour process theorists would see conflict as emanating from inequalities inherent in organizational life. For them, conflict emerges from class struggle for power and control and would serve to bring about change (Salamon, 1992). This view appears to only recognize conflicts between line and staff positions or between labour and management to the exclusion of those that occur within the individual, between the individual and his/her work group or between work groups in the organization. Nonetheless, it seems plausible to suggest that the labour process perspective may have informed Mullins and Christy's (2013:99) view that "greater attention should be given to relationships ... and [to] the study of conflict between the needs of the individual and those of the organization ...".

Another distinctive perspective is the interactionist view which submits that conflict has positive attributes. In this perspective, some level of conflict should actually be encouraged for effective performance. Proponents believe that a workplace devoid of conflict and as such replete with harmony, peace, cooperation and tranquility is likely to become static, apathetic and unresponsive to strategic organizational needs (Robbins, Judge, and Vohra, 2011; Singh, 2013; Mullins and Christy, 2013). They argue that minimal levels of conflict could be constructive and functional in that it keeps the group viable by encouraging self criticism and creativity, thereby making change and innovation possible. For instance, Aylott (2014:62) is certain that "... without different opinions we cannot improve and develop ideas or products". For her also, creativity is enhanced only if a climate that accepts conflicting viewpoints exists. From an interactonist perspective therefore, conflict is inevitable; is not necessarily good or bad but essentially causes an issue to be looked at from different perspectives (Weihrich et al, 2011) and "should be judged in terms of its effect on performance" (Mullins and Christy, 2013:99).

Relatedly, the pluralist perspective would suggest that conflict is not necessarily always dysfunctional but as Mullins and Christy (2013:99) agree "can be an agent of evolution and internal and external change". For them, all that is required by the manager is "careful handling and attempt to reconcile rival interests". Herein lies the very essence of conflict management strategies and styles practiced in organizations. 
In any event, we need to recognize the distinction between conflict resolution and conflict management as noted by some analysts although both concepts are also often used interchangeably. In this respect, conflict resolution is seen as having to do with complete elimination or termination of identified conflict whilst conflict management concerns minimization of the negative and maximization of the positive outcomes of conflict so as to improve organizational learning, development and performance (Dechurch and Marks, 2001; Rahim, 2002). However, the interest of the current study lies in the latter, the management of conflict.

\subsection{Conflict Management Styles}

The literature on the handling of conflict is diverse as enormous attention is given to the phenomenon in organizations. The need for a harmonious work environment is a strategic concern but problematic. Thus, Aylott (2014:38) remarks that there is a struggle with the management of conflict “ $\ldots$ because employees' responses are primitive and can be emotional". The diverse propositions concerning the handling of conflict could be streamlined into: (i) Those which seem to focus on defined potential areas of conflict and recommend strategies to prevent or nip conflict in the bud. For example, Mullins and Christy (2013) provide a list of potential areas of conflict and describe strategies for prevention.

(ii) Those geared toward dealing with the conflict when it actually festers. The remit of this study lies in this second category which, for our concerns, we take as conflict management styles.

As stated earlier, the Thomas-Kilman model (1974; in Singh, 2013) identifies five conflict styles each of which has its consequences. The styles include competing, collaborating, compromising, avoiding and accommodating styles which are defined by their levels of assertiveness and cooperativeness.

(i) Competing Styles: This focus on the realization of one's own goals and an unwillingness to recognize the concerns of others. The style has little regard for the maintenance of relationship and relies enormously on coercive power.

(ii) Collaborating Style: This seeks to satisfy the concerns of all the parties in the conflict. It is characterized by both cooperation and assertiveness as well as the search for a mutually satisfactory outcome in so far as it "offers the chance for consensus (Singh 2013:33). Also very importantly, collaboration serves to maintain and strengthen work relationships (Snell, 2002).

(iii) Compromising Style: This is a "give and take" approach wherein parties give up something such that there is no clear winner or loser. No party achieves complete satisfaction of needs and goals. That is, a solution that provides incomplete satisfaction is accepted by the parties involved. The style is neither highly cooperative nor highly assertive thus resulting in satisficing rather than maximizing solutions (Snell, 2002).

(iv) Avoiding Style: This is defined by non-action. The conflict is viewed in negative terms and is not addressed. Preference here is to withdraw, do nothing, as it were, and hoping that the conflict would pass. Kassim and Ibrahim (2014) observe that this approach serves to reduce tension and to stall for more time.

(v) Accommodating Style: This is a non-assertive style which is opposite to competing. It seeks to achieve an atmosphere of harmony by a neglect of personal needs and interests, the thrust being to satisfy the needs of the other party.

Related to the collaborative style is the integrative approach. This style, found in Rahim-Magner model (1995) is characterized by joint problem solving wherein there is openness and objectivity in confronting differences (Weihrich et al., 2011). That is, parties to the conflict work towards finding a solution that is acceptable to all rather than seeking to compromise or to suppress the conflict (Singh, 2013). In this, the parties actually confront the conflict, each party expressing its views to the other. Views so brought to light are critically examined such that each party tries to understand the others point of view. Subsequently efforts are made to identify and utilize methods for resolving the conflict, such that benefits all parties. Although many of these conflict management styles appear to be appropriate for individual level analysis, this study accepts Singh's (2013) view that the styles, could also be applied at the organizational level.

\subsection{Industrial Harmony}

Harmony in the organization suggests the existence of agreement in ideas, values and a general togetherness of organizational members. It seems plausible to suggest that achieving industrial harmony is dependent on the existence of an organizational climate wherein trust, support and cooperation exist. Hence a harmonious work environment is likely to be characterized by members pulling efforts together and, relationship between and among individuals and groups are cordial and productive. In conditions of disharmony, on the other hand, there is likely to be open hostility, distrust, disrespect, non cooperation and avoidance of interaction (Hatch and Cunliffe, 2013). In this scenario, organizational processes are likely to be disrupted and so would they be disruptions in the provision of goods and services.Industrial harmony may be assessed in terms of low incidence of strike activity and the level of mutuality in the employment relationship. Strike refers to a stoppage of work activities in a work organization or industry by employees who act in combination in pursuance of a concerted plan (Singh 2013). Strikes occur when there is discontentment among workers. 
According to Fashoyin (1992:176), "strike indicates a breakdown of cordial relationship between labour and management". Similarly, Fajana (2002:58-62) sees strike as an open manifestation of industrial conflict which may arise from a "... failure to honour commitments to ... workers". In unionized firms, strikes are embarked upon to mount pressure on the employer to force it to concede to union demands, which frequently are hinged on improvements in employment terms and working conditions. Concession to union demands would occur when management is concerned about loss in output and hence profit although, as Fashoyin (1992) submits, a protracted strike could also exert costs on the rank and file who may be forced to scale down their expectations.

Mutuality on the other hand, concerns the existence of reciprocity among work people. It is hinged on the unitarist "belief that management and employees share the same concerns and it is ... in both their interests to work together" (Armstrong, 2009:9). Mutuality suggests a positive employment relationship which recognizes the interdependency of employers and employees and from which both parties benefit (Armstrong, 2009). In effect, mutuality seeks to get across the message on the importance of togetherness. As Aylott (2014:36) similarly remarks, "mutuality describes the reliance of both parties on each other, an interdependence or partnership". On one hand, employees need work from the employer to earn a living and on the other hand, employers need employees to produce goods and services for profit. Thus for Armstrong (2001:739), mutuality suggests that "the interests of management and employees coincide".

Further, Walton (1985a in Armstrong, 2009) makes the point that a theory of mutuality would be promoted by HRM policies which recognize "mutual goals, mutual influence, mutual respect, mutual rewards [and] mutual responsibility". According to him, such policies are likely to encourage workers commitment which, most probably, would translate to "better economic performance and greater human development". Following from the above, it seems safe to suggest that a policy of mutuality would serve to deemphasize the differentness of the two sides in the employment relationship, each party being receptive and indeed empathetic to the concerns of the other.

\subsection{Conflict Management Styles and Industrial Harmony}

A preference for industrial peace and harmony in work organizations is a given. As stated earlier, in a harmonious work environment, the climate is characterized by mutual trust, respect and cooperation all of which positively influence performance in the organization. The reverse holds in conditions of disharmony. It has also been noted that the web of interdependencies and incompatibilities inherent in work organizations provide endless avenues for conflict (Snell, 2002; Weihrich et al., 2011; Singh, 2013; Mullins and Christy, 2013; Ayllot, 2014). Whilst some organizational conflicts are healthy and constructive (Robbins et al. 2011) others are destructive “. . . with a damaging effect on trust and respect ..." (Aylott, 2014:64). It is presumable that contending with destructive conflict in order to, hopefully, achieve harmony warrant the existence of varied conflict management styles.

Nonetheless, analysts suggest that there is no clear cut right or wrong conflict management style, the right style being a function of the situation at a given time (Hocker and Wilmot, 1985 in Kassim and Ibrahim, 2014; Snell, 2002). As Snell (2002) explains, competing is healthy when, among others, it encourages motivation; compromise is useful in situations of time pressure wherein a temporary solution would suffice. With regard to accommodating, it seems necessary when people realize they are in the wrong or are outmatched. Avoiding style seems appropriate when confronted with a trivial issue or, addressing the conflict does not lie in one's domain. Finally, collaboration may be the ideal response when the parties have valid issues and concerns which need creative solutions and which in turn require the commitment of all for implementation.

However, in this study, we exclude the competing style in the conviction that a management that seeks harmony would not overly ignore the concerns of employees. Also, we do not explore the avoiding style. This is because we doubt the likelihood that management would adopt this style in a manufacturing setting. Here, it is not likely that management would opt for inaction. Therefore, our focus is on three (3) styles namely, collaborating, compromising and accommodating styles. To investigate whether there is a relationship between these styles and industrial harmony, we propose the following hypothesis: There is no relationship between collaborating, compromising or accommodating conflict management styles and industrial harmony indexed by low incidence of strike activity and mutuality.

\section{Methodology}

The study was a snap- short survey of 10 manufacturing firms in Port Harcourt, Nigeria. The population of the study was 642 employees made up of both managerial and junior employees. A sample size of 240 was determined using the Krejcie and Morgan (1972) table. Equal numbers of copies of the research questionnaire (24 copies) were distributed to each of the firms. A total of $226(94 \%)$ copies of the questionnaire were returned and of these, $219(91 \%)$ were usable. Questionnaire items were developed from extant literature. However, some items on conflict management styles, the predictor variable, were adapted from measures used in Kassim and Ibrahim's (2014) study. The constructs for conflict management styles had a total of 15 items 
broken down into: Collaborating style (6 items), compromising style (5 items) and accommodating style (4 items). Industrial harmony, the criterion variable, which had 5 items were measured by low incidence of strike (3 items) and mutuality (2 items).

Responses on the questionnaire items were scored on a 4-point likert type scale which ranged from strongly agree (4) to strongly disagree (1). Evaluating of the reliability of the study instrument yielded Cronbach's Alpha coefficients above 0.70, Nunally's (1978) recommended benchmark (table 1). The data collected were analysed using descriptive statistics for all questionnaire items and Spearman's Rank Order statistical tool to test the hypothesis.

\section{Data Analysis}

Table 1: Reliability Test On The Study Variables

\begin{tabular}{|ll|l|}
\hline CRONBACH'S Alpha & NO OF ITEMS \\
\hline Collaboration & .992 & 6 \\
Compromising & .976 & 4 \\
Accommodating & .990 & 5 \\
Low Incidence of Strike & .798 & 3 \\
Mutuality & .981 & 2 \\
\hline
\end{tabular}

Table 2: Descriptive Statistics for Study Variables

\begin{tabular}{|c|c|c|c|c|c|}
\hline CONFLICT MANAGEMENT STYLES & $\mathbf{N}$ & Minimum & Maximum & Mean & Std. deviation \\
\hline 1. Collaborating & 219 & 1 & 4 & 2.50 & .985 \\
\hline $\begin{array}{l}\text { In my organization, parties in conflict work together to find } \\
\text { solution acceptable to all. }\end{array}$ & 219 & 1 & 4 & 2.49 & .974 \\
\hline $\begin{array}{l}\text { Conflict situations in my organization are often critically } \\
\text { analyzed to identify the real concern of the parties in order } \\
\text { to find satisfactory solutions. }\end{array}$ & 219 & 1 & 4 & 2.39 & 1.000 \\
\hline $\begin{array}{l}\text { In my organization, concerns are brought in the open so that } \\
\text { the most acceptable solution can be found. }\end{array}$ & 219 & 1 & 4 & 2.53 & .930 \\
\hline $\begin{array}{l}\text { Management in my organization often use the best solution } \\
\text { agreeable to the majority. }\end{array}$ & 219 & 1 & 4 & 2.53 & 1.015 \\
\hline $\begin{array}{l}\text { In my organization, conflicts are resolved by joint decision } \\
\text { making. }\end{array}$ & 219 & 1 & 4 & 2.56 & 1.000 \\
\hline $\begin{array}{l}\text { There is open communication and exchange of accurate } \\
\text { information in my organization to enable joint problem } \\
\text { solving. }\end{array}$ & 219 & 1 & 4 & 2.51 & .992 \\
\hline Compromising & 219 & 1 & 4 & 2.48 & .960 \\
\hline $\begin{array}{l}\text { Management in my organization seeks to find solutions that } \\
\text { partially satisfy the concerns of conflicting parties. }\end{array}$ & 219 & 1 & 4 & 2.43 & .995 \\
\hline $\begin{array}{l}\text { When conflict occurs in my organization, management } \\
\text { change their position in order to avoid breakdown in } \\
\text { relationship with workers. }\end{array}$ & 219 & 1 & 4 & 2.29 & .907 \\
\hline $\begin{array}{l}\text { In my organization, management tries not to be } \\
\text { confrontational in conflictual situations. }\end{array}$ & 219 & 1 & 4 & 2.66 & .998 \\
\hline $\begin{array}{l}\text { When conflict arises, management in my organization } \\
\text { usually proposes a middle ground for breaking the } \\
\text { deadlock. }\end{array}$ & 219 & 1 & 4 & 2.53 & .940 \\
\hline Accommodating & 219 & 1 & 4 & 2.47 & .966 \\
\hline $\begin{array}{l}\text { In my organization, conflicting parties do not seek to win all } \\
\text { of the time. }\end{array}$ & 219 & 1 & 4 & 2.48 & 1.015 \\
\hline $\begin{array}{l}\text { In my organization, management neglects its concerns to } \\
\text { satisfy the concerns of workers. }\end{array}$ & 219 & 1 & 4 & 2.44 & .986 \\
\hline $\begin{array}{l}\text { Management in my organization often goes along with } \\
\text { employee demands. }\end{array}$ & 219 & 1 & 4 & 2.42 & .942 \\
\hline Management always tries to satisfy workers expectations. & 219 & 1 & 4 & 2.47 & .973 \\
\hline $\begin{array}{l}\text { In conflictual situations, management considers the views of } \\
\text { employees so to avoid prolonging conflict. }\end{array}$ & 219 & 1 & 4 & 2.53 & .915 \\
\hline \multicolumn{6}{|l|}{ INDUSTRIAL HARMONY } \\
\hline Low Incidence of Strike & 219 & 1 & 4 & 2.46 & .972 \\
\hline $\begin{array}{l}\text { In my organization, strike activity is generally seen as } \\
\text { unnecessary. }\end{array}$ & 219 & 1 & 4 & 2.37 & .975 \\
\hline $\begin{array}{l}\text { Confrontation between management and employees is } \\
\text { almost nonexistent in my organization. }\end{array}$ & 219 & 1 & 4 & 2.44 & .995 \\
\hline $\begin{array}{l}\text { In my organization, a cordial relationship exists between } \\
\text { management and workers. }\end{array}$ & 219 & 1 & 4 & 2.58 & .946 \\
\hline Mutuality & 219 & 1 & 4 & 2.55 & .909 \\
\hline $\begin{array}{l}\text { In my workplace, an air of togetherness exists among } \\
\text { organization members. }\end{array}$ & 219 & 1 & 4 & 2.52 & .880 \\
\hline $\begin{array}{l}\text { Management and employees in my organization rely on one } \\
\text { another to achieve their goals. }\end{array}$ & 219 & 1 & 4 & 2.57 & .938 \\
\hline
\end{tabular}




\subsection{Descriptive Statistics}

The mean scores and standard deviations of all study variables are presented in table 2 . The table reveals that while the overall mean for the collaborating style is $2.50,4$ out of the 6 items used to measure the style had means just above the average of 2.50 , the highest ( $\mathrm{M}=2.56$; SD 1.000) recorded by the item which stated that "... conflicts are resolved by joint decision making". The lowest mean $(2.39$; SD $=1.000)$ was recorded by the item that: "conflict situations... are often critically analyzed to determine the real concerns of parties in order to find satisfactory solutions". With regard to the compromising style, the overall mean score is 2.48. However, the highest mean score $(\mathrm{M}=2.66, \mathrm{SD}=0.998)$ was recorded by the item that " $\ldots$ management tries not to be confrontational in conflictual situations". The lowest mean $(\mathrm{M}=2.29 ; \mathrm{SD}=0.907)$ was recorded by the item that "when conflict occurs ... management change their position in order to avoid breakdown in relationship with workers".

For the accommodating style with an overall mean score of 2.47 , only one item, “... in conflictual situations, management considers the views of employees so to avoid prolonging conflict" scored a mean above average $(\mathrm{M}=2.53$; $\mathrm{SD} 0.915)$. The lowest mean $(\mathrm{M}=2.42 ; \mathrm{SD} 0.942)$ was recorded for the item that "management... often goes along with employee demands". Low incidence of strike, one of the measures of industrial harmony, has its overall mean as 2.46 and the highest mean $(\mathrm{M}=2.58 ; \mathrm{SD}=0.946)$ was recorded by the item that "... a cordial relationship exists between management and workers". The lowest mean $(\mathrm{M}=2.37$; $\mathrm{SD}=0.975)$ was gotten for the item that “... strike activity is generally seen as unnecessary". Each of the 2 items used to assess mutuality, the second measure for industrial harmony, recorded means above average $(\mathrm{M}=$ 2.57; $\mathrm{SD}=0.938$ and $\mathrm{M}=2.52 ; \mathrm{SD}=0.880$ ), the higher mean recorded by the item that "management and employees ... rely on one another to achieve their goals" and the lower mean by the item that "... an air of togetherness exists among organization members". Implicitly, the result suggests that the contribution of the mutuality element to harmony in the workplace is considerable.

\subsection{Test of Hypotheses}

Spearman Rank correlation was used to test the hypothesis which states that there is no relationship between collaborating, compromising or accommodating conflict management styles and industrial harmony indexed by the low incidence of strike and mutuality. As results of the correlation analysis in table 3 show, strong, positive and significant relationship exist between all dimensions of conflict management styles and measures of industrial harmony evidenced by correlation coefficients ( $r$ ) which range from 0.953 to 0.996 at $p<$ 0.05. Therefore, we reject the null hypothesis and accept that a significant relationship exist between the conflict management styles used in the study and industrial harmony. However, the collaborating style ranked highest recording correlation coefficients (r) of 0.996 and 0.962 for low incidence of strike and mutuality respectively. The accommodating style follows with $r=0.991$, higher than for the compromising style $(r=0.982)$ with regard to low incidence of strike. The difference in the values of ( $r$ ) for both styles in relation to mutuality are very minimal (0.953 and 0.954).

Table 3: The Coefficients of Correlations of Conflict Management Styles and Industrial Harmony

\begin{tabular}{|c|c|c|c|c|c|c|c|}
\hline & & & COLLABORATING & COMPROMISING & ACCOMMODATING & $\begin{array}{l}\text { INCIDENCE } \\
\text { OF STRIKE }\end{array}$ & MUTUALITY \\
\hline \multirow[t]{15}{*}{$\begin{array}{l}\text { Spearman's } \\
\text { rho }\end{array}$} & \multirow[t]{3}{*}{ COLLABORATING } & $\begin{array}{l}\text { Correlation } \\
\text { Coefficient }\end{array}$ & 1.000 & $.983^{* *}$ & $.992^{* *}$ & $.996^{* *}$ & $.962^{* *}$ \\
\hline & & Sig. (2-tailed) & & .000 & .000 & .000 & .000 \\
\hline & & $\mathrm{N}$ & 219 & 219 & 219 & 219 & 219 \\
\hline & \multirow[t]{3}{*}{ COMPROMISING } & $\begin{array}{l}\text { Correlation } \\
\text { Coefficient }\end{array}$ & $.983^{* *}$ & 1.000 & $.981^{* *}$ & $.982^{* *}$ & $.954^{* *}$ \\
\hline & & Sig. (2-tailed) & .000 & & .000 & .000 & .000 \\
\hline & & $\mathrm{N}$ & 219 & 219 & 219 & 219 & 219 \\
\hline & \multirow[t]{3}{*}{$\begin{array}{l}\text { ACCOMMODATIN } \\
\text { G }\end{array}$} & $\begin{array}{l}\text { Correlation } \\
\text { Coefficient }\end{array}$ & $.992^{* *}$ & $.981^{* *}$ & 1.000 & $.991^{\circ *}$ & $.953^{* *}$ \\
\hline & & Sig. (2-tailed) & .000 & .000 & & .000 & .000 \\
\hline & & $\mathrm{N}$ & 219 & 219 & 219 & 219 & 219 \\
\hline & \multirow[t]{3}{*}{$\begin{array}{l}\text { INCIDENCE } \\
\text { STRIKE }\end{array}$} & $\begin{array}{l}\text { Correlation } \\
\text { Coefficient }\end{array}$ & $.996^{* *}$ & $.982^{* *}$ & $.991^{\circ *}$ & 1.000 & $.961^{* *}$ \\
\hline & & Sig. (2-tailed) & .000 & .000 & .000 & & .000 \\
\hline & & $\mathrm{N}$ & 219 & 219 & 219 & 219 & 219 \\
\hline & \multirow[t]{3}{*}{ MUTUALITY } & $\begin{array}{l}\text { Correlation } \\
\text { Coefficient }\end{array}$ & $.962^{* *}$ & $.954^{* *}$ & $.953^{* *}$ & $.961^{* *}$ & 1.000 \\
\hline & & Sig. (2-tailed) & .000 & .000 & .000 & .000 & \\
\hline & & $\mathrm{N}$ & 219 & 219 & 219 & 219 & 219 \\
\hline
\end{tabular}

**. Correlation is significant at the 0.05 level (2-tailed).

Further, concerning the collaborating style, the coefficients of determination $\left(\mathrm{r}^{2}\right)$ of 0.992 and 0.925 for low incidence of strike and mutuality respectively suggest that based on conflict management styles $99 \%$ of a low incidence of strike and $93 \%$ of mutuality can be explained by the collaborating style. For the accommodating style, coefficients of determination $\left(\mathrm{r}^{2}\right)$ of 0.982 and 0.908 for low incidence of strike and mutuality respectively suggest that $98 \%$ of a low strike incidence and $91 \%$ of mutuality could be accounted for by the accommodating style. With regard to the compromising style, the coefficients of determination $\left(\mathrm{r}^{2}\right)$ are 
0.964 and 0.910 respectively for low incidence of strike and mutuality implying that $96 \%$ of the former and $91 \%$ of the latter can be explained by the compromising style.

\section{Discussion Of Findings, Conclusion And Recommendations}

The study set out to find out whether the conflict management styles studied are used in the organizations studied and if they are, the extent to which they are associated with industrial harmony. As the results of the univariate analysis of the study variables show overall, there appears to be an average or close to average use of all the conflict management styles studied.

A number of observations from the results are notable. First, in the assessment of the collaborating style, the highest mean (2.56) was recorded by the item which suggested that conflicts are resolved via joint decision making. Similarly for the accommodating style, consideration of the views of employees in order to avoid conflict scored the highest mean (2.53). These results are in tandem with views in the literature concerning the importance of encouraging employee involvement (Likert and Likert, 1976; Goss, 1996; Johnstone, S. and Ackers, P. 2015). Thus, it is presumable that using these styles would, in so far they encourage employee involvement, help achieve harmony in the workplace.

Further, the item which had the lowest mean in the collaborating style (2.39; SD 1.000) is that which assessed whether parties engage in a critical analysis of conflict situations in order to identify the real concerns of parties so as to find satisfactory solutions. This result suggests that in the organizations studied, not much use is made of a real problem-solving approach in addressing conflict when they arise. Also, under the accommodating style, that the item which states that "management ... often goes along with employee demands" recorded the lowest mean $(\mathrm{M}=2.42$; $\mathrm{SD}=0.942)$ suggests that in these organizations, management is unable to let employees dictate the terms of the relationship. Hence, it appears the accommodating style is only in the extent that employees are given opportunities to express their views. For the compromising styles, results on the item that management is prone to changing its position to avoid breakdown in their relationship with workers scored the lowest mean $(\mathrm{M}=2.29$; $\mathrm{SD}=0.907)$, suggesting that management is unwilling to be the underdog, a seeming reiteration of employers right to manage. In this regard Aylott 92014:48) had observed that “... if employees continuously questioned management decisions, and mangers were not left to manage, no work would ever get completed". Nonetheless, management striving to be non-confrontational recorded the highest mean ( $M=2.66$; SD 0.998) which implies that they actually desire peace in the workplace.

The analyses on industrial harmony are also revealing. Considering the results on strike incidence, that the item on the existence of a cordial relationship attracted an above average mean score $(\mathrm{M}=2.58 ; \mathrm{SD}=0.946)$ suggest the existence of relative harmony. However, the below average mean score $(\mathrm{M}=2.37$; $\mathrm{SD}=0.975)$ on the item that members see strike as unnecessary is quite illuminating. It seems plausible to submit that a cordial relationship may exist between management and the managed but this does not, in the least, preclude strike activity. The strike weapon can be called to use as the need arises. The assessment of mutuality showed that both items used recorded mean scores above average $(\mathrm{M}=2.57$; $\mathrm{SD} 0.938$ and $\mathrm{M}=2.52$; SD 0.880). These, by implication, suggest that seeking to maintain mutuality in the workplace will help organizations achieve relative harmony in so far as the principle entails mutuality of goals and influence, respect, reward, and responsibility (Walton 1985a in Armstrong, 2009).

Results of the correlation analysis indicate that all 3 conflict management styles positively correlate industrial harmony though apparently more so with the collaborating style. Perhaps, the collaborating style in particular really does serve to maintain and strengthen work relationships (Snell, 2002) and does help in consensus building (Singh, 2013) between employers and employees resulting in reduced incidence of strike. Also, collaboration appears to be compatible with the principles of mutuality and as such could positively bear on the achievement of relative harmony in the workplace.

Nevertheless, the findings of this study must be taken with some caution principally, for reason of methodological limitations. First, the study was a snap-shot survey which means we cannot safely impute a causal relationship between the predictor and criterion variables. Further, the possible industry - specific bias arising from the heterogeneity of the firms studied limits the generalizability of the findings. Also, the study excluded other work-related variables which could impinge on the variables investigated. Besides, the equal distribution of copies of the questionnaire among the firms ignores the possible influence of firm-size. Also notable is the bias associated with the tendency of respondents to give responses they perceive as socially desirable rather than in consonance with reality (Kassim and Ibrahim, 2014). In effect, the descriptive analysis of the study variables and their relationships should also be treated with caution.

These limitations notwithstanding, the study has revealed that there is about an average use of the conflict management styles and they all influence workplace harmony just as, according to Rahim and Buntzman, (1984) and Kassim and Ibrahim, (2014) studies, they do predict employees commitment to the organization. However, we take the view that the just average use of the styles suggest the need to look beyond conflict management styles to explain the control of conflict for the achievement of relative harmony in 
organizations. Nevertheless, taking the results together, we believe that an even greater involvement of employees in joint decisions on conflict issues as well as extending the collaborating style to embrace more integrative problem-solving would help enhance harmony in the workplace.

\section{References}

[1]. Akume, A. \& Abdullahi, Y. (2013). Challenges and prospects of effectives industrial conflict resolution in Nigeria . Journal of social sciences, 36(2), 119-208.

[2]. Appellaum, S; Abdallah, C. \& Shapiro, B. (1999). The self-directed team: A conflict resolution analysis. Team performance management, 5(2), 60-77.

[3]. Armstrong, M. (2001). A handbook of human resource management practice ( $8^{\text {th }}$ ed.). London: Kogan Page.

[4]. Armstrong, M. (2009). Armstrong's handbook of human resource management practice (11 ${ }^{\text {th }}$ ed.). London: Kogan Page.

[5]. Aylott, E. (2014). Employee relations. London: Kogan Page.

[6]. Bassey, A; Ojua, T.; Archibong, E.; Bassey, U. (2012). The impact of inter-union conflicts on industrial harmony: The case of tertiary health institutions in Cross River State, Nigeria. Malaysia journal of society and space, 8(4) 33-39.

[7]. Chan, K., Huang, X. \& Peng, M. (2008). Managers' conflict management styles and employee attitudinal outcomes: The mediating role of trust. Asia pacific Journal of management, 25(2) 277-295.

[8]. Coser, L. (1967). Continuities in the study of conflict. New York: Free Press.

[9]. Deutsch, M. (1973). The resolution of conflict: New Haven CT: Yale University Press.

[10]. Fajana, S. (2002). Human resource management: An Introduction. Lagos: Labofin and Company.

[11]. Fashoyin, T. (1992). Industrial relations in Nigeria $\left(2^{\text {nd }}\right.$ ed.) Nigeria: Longman.

[12]. Goss, D. (1996). Principles of human resource management. London: Routledge.

[13]. Green, B. \& Marks, M. (2001). Maximizing the benefits of task conflict: The role of the conflict management. International journal of conflict management. 12(1), 4-22.

[14]. Hatch, M. \& Cunliffe, A . (2013). Organization theory, modern, symbolic, and postmodern perspectives ( $3^{\text {rd }}$ ed.). United Kingdom: Oxford.

[15]. Johnstone, S. \& Ackers, P. (2015). Finding A voice at Work? New perspectives on employment relations. United Kingdom: Oxford University Press.

[16]. Kassim, M. \& Ibrahim, H. (2014). Conflict management styles and organizational commitment: A study among bank employees in Penang. International journal of business, economics and law. 4, (1), 45-53.

[17]. Likert, R. \& Likert, J. (1976). New ways of managing conflict. New York: McGraw-Hill.

[18]. Mullins, L. \& Christy, G. (2013). Management and organizational behaviour (10th ed.). UK: Pearson.

[19]. Okpu, T. \& Kpakol, A. (2015). Managing employee trust perceptions for sustained workplace harmony in the Nigeria banking industry. International journal of management studies and research, 3(5), 65-73.

[20]. Rahim, M. \& Bonama, T. (1979). Managing organizational conflict: A model for diagnosis and intervention. Psychological reports, 44 (3), 1323-1344.

[21]. Rahim, M. \& Buntzman, G. (1989). Supervisory power bases, styles of handing conflict with subordinates, and subordinate compliance and satisfaction. Journal of psychology, 123, 195-210.

[22]. Rahim, M. \& Magner, N. (1995). Confirmatory factor analysis of the styles of handling interpersonal conflict: First-order factor model and its invariance across groups. Journal of applied psychology. 80, 122-132.

[23]. Rahim, M. (2002). Toward a theory of managing organizational conflict. The International journal of conflict management, 13(3), 206-235.

[24]. Robbins, S., Judge, T; \& Vohra, N. (2011). Organizational behaviour (14 ${ }^{\text {th }}$ ed.). USA: Pearson as Prentice Hall.

[25]. Salamon, M. (1992). Industrial relations. Cambridge: Prentice Hall.

[26]. Singh, S. (2013). Industrial relations. Delhi: AITBS publishers.

[27]. Snell, B. (2002). Management: Competing in the new era. McGraw-Hill: New York.

[28]. Weihrich, H., Cannice, M. \& Koontz, H. (2011). Management: A global and entrepreneurial perspective (13 ${ }^{\text {th }}$ ed.). New Delhi: Tata McGraw Hill. 